\title{
艘 \\ ISLAM DAN BUDAYA DI BANTEN: Menelisik Tradisi Debus Dan Maulid
}

\author{
Hasani Ahmad Said \\ UIN Syarif Hidayatulloh Jakarta \\ hasaniahmadsaid@uinjkt.ac.id
}

\begin{abstract}
Abstrak
Sejarah mencatat pada awal abad 19, Banten menjadi rujukan para ulama di Nusantara, bahkan di Asia Tenggara, khususnya tentang ilmu keIslaman. Kebudayaan Banten, yang nampak sederhana, sesungguhnya memiliki kompleksitas yang tinggi. Artikel ini mengetengahkan potret budaya Banten dengan memfokuskan pada dua pokok bahasan yakni atraksi debus dan tradisi Panjang Maulid. Penelitian menemukan bahwa beragamnya seni pertunjukan kesenian rakyat Banten, yang berkembang secara turun temurun, tidak terlepas dari pengaruh keagamaan, khususnya Islam.
\end{abstract}

\begin{abstract}
In the early of 19th century, Banten had became the reference of the scholars in the archipelago, even in Southeast Asia, particularly on the Islamic studies. The Bantenese culture, which seems very simple, actually has a high complexity. This article explores the portraits of Bantenese cultures by focusing on two issues namely Debus attractions and Panjang Mawlid tradition. The study finds out that the diversity of art performance of Bantenese culture, evolving from generation to generation, can not be separated from the influences of religion, especially Islam.
\end{abstract}

Key Word : Islam, budaya, debus, dzikir, mulud 


\section{A. Pendahuluan}

Islam dalam tataran teologis adalah sistem nilai dan ajaran yang bersifat Ilahiyah dan transenden. Sedangkan dalam perspektif sosiologis, Islam merupakan fenomena peradaban, kultural dan realitas sosial dalam kehidupan manusia. Antara Islam dalam tataran teologis dan sosiologis yang merupakan realitas kehidupan sejatinya merupakan realitas yang terus menerus menyertai agama ini sepanjang sejarahnya.

Kontak awal Islam dengan kepulauan nusantara mayoritas berlangsung di pesisir pantai, khususnya melalui aktivitas perdagangan antara penduduk lokal dengan para pedagang Persia, Arab, dan Gujarat (India). Kontak-kontak ini memungkinkan proses asimilasi, sinkretisasi, dan akulturisasi budaya. Hal ini berarti bahwa Islam tidaklah menyusun bangunan peradaban, tetapi lebih tepatnya Islam menyelaraskan dengan peradaban. ${ }^{1}$ Sejak zaman Rasulullah saw, Islam disampaikan dengan beragam cara, didakwahkan kepada umat dengan berbagai metode. Dalam perkembangannya, Islam tidak dapat dipisahkan dengan budaya, bahkan Islam merangkul budaya untuk menyampaikan ajarannya. ${ }^{2}$

Supartono Widyosiswoyo ${ }^{3}$ ketika mengurai tentang teori masuknya Islam ke nusantara, ${ }^{4}$ menurutnya penetrasi Islam

\footnotetext{
${ }^{1}$ Baca lebih jauh, Clifford Geertz, Agama di Jawa: Konflik dan Interaksi, dalam : Roland Robertson (ed), Agama dalam Analisis dan Interpretasi Sosiologi, (Jakarta: Rajawali, 1992); baca pula, M. Amin Abdullah, Studi Agama, Normativitas atau Historisitas, (Yogyakarta: Pustaka Pelajar, 1996); baca pula, Muhaimin AG, Islam Dalam Bingkai Budaya Lokal Potret dari Cirebon, (Jakarta: P.T. Logos Wacana Ilmu, 2002); lihat pula, Ahmad Syafi i Maarif, Membumikan Islam, (Yogyakarta: Pustaka Pelajar, 1995).

2 Ahmad Elfatah, "Hubungan Agama dan Budaya dalam Islam", diakses dari http://www.dakwatuna.com/2012/12/25136/hubungan-budaya-danagama-dalam-islam/\#ixzz2OckVdWFU

${ }^{3}$ Supartono Widyosiswoyo, Sejarah Kebudayaan Indonesia (Jakarta: Universitas Trisakti, Cet.2, 2006), h. 96-100.

${ }^{4}$ Setidaknya, ada beberapa pendapat tentang masuknya Islam ke Indonesia. Pertama, Islam yang masuk dan berkembang di Indonesia berasal dari Jazirah Arab atau bahkan dari Makkah pada abad ke-7 M, pada abad
} 
dibagi ke dalam tiga jalur yaitu: Jalur Utara, Jalur Tengah, dan Jalur Selatan. Ketiga jalur didasarkan pada pangkal wilayah persebaran Islam yang memasuki Indonesia. Jalur Utara adalah masuknya Islam dari Persia dan Mesopotamia. ${ }^{5}$ Jalur Tengah adalah masuknya Islam dari bagian barat lembah Sungai Yordan dan bagian timur semenanjung Arabia (Hadramaut). ${ }^{6}$ Jalur Selatan pangkalnya di wilayah Mesir. Saat itu Kairo merupakan pusat penyiaran agama Islam modern dan Indonesia memperoleh pengaruhnya dalam organisasi keagamaan semisal Muhammadiyah, NU, dan melalui pemikiran-pemikiran tokoh-tokoh Islam Nusantara yang pernah belajar ke Timur Tengah. Kegiatan lewat jalur ini terutama

pertama Hijriah. Kedua, Islam dibawa dan disebarkan di Indonesia oleh orangorang Cina. Ketiga, Islam yang masuk ke Indonesia berasal dari Gujarat pada abad ke-12 M. dan keempat, Islam yang masuk ke Indonesia berasal dari Persia. Hal ini seperti telah diungkap oleh Djajaningrat yang dikenal sebagai orang Indonesia pertama yang mempertahankan disertasi di Universitas Leiden, Belanda, pada 1913. Disertasinya itu berjudul Critische Beschouwing van de Sadjarah Banten (Pandangan Kritis mengenai Sejarah Banten). Baca lebih lanjut, “Masuknya Islam ke Indonesia”, Majalah Konsultasi Kita, Edisi Perdana, h. 5456.

${ }^{5}$ Dari sana, Islam bergerak ke timur lewat jalur darat Afganistan, Pakistan, Gujarat, lalu menempuh jalur laut menuju Indonesia. Lewat Jalur Utara ini, Islam tampil dalam bentuk barunya yaitu aliran Tasawuf. Dalam aliran ini, Islam didifusikan lewat pengalaman personal (eksperensial) dalam mendekati Tuhan. Aliran inilah yang paling cepat mendorong konversi penduduk Indonesia ke dalam Islam nusantara. Aceh adalah salah satu basis persebaran Islam Jalur Utara ini.

${ }^{6}$ Dari sini Islam menyebar dalam bentuknya yang relatif asli, di antaranya aliran Wahhabi. Pengaruhnya mengena di wilayah Sumatera Barat. Jalur ini terjadi sebab jika bertolak dari Hadramaut, maka dengan perjalanan laut orang-orang Islam langsung sampai ke pantai barat Sumatera. Konflik kaum adat dengan kaum agama dalam Perang Paderi terjadi setelah pengaruh Islam lewat jalur ini. 
perdagangan, ${ }^{7}$ perkawinan, ${ }^{8}$ tasawuf,, 9 pendidikan, ${ }^{10}$ dakwah,

${ }^{7}$ Perdagangan merupakan metode penetrasi Islam paling kentara. Dalam proses ini, pedagang nusantara dan Islam asing bertemu dan saling bertukar pengaruh. Pedagang asing umumnya berasal dari Gujarat dan Timur Tengah (Arab dan Persia). Mereka melakukan kontak dengan para adipati wilayah pesisir yang hendak melepaskan diri dari kekuasaan Majapahit. Sebagian dari para pedagang asing ini menetap di wilayah yang berdekatan dengan pantai dan mendifusikan Islam mereka.

${ }^{8}$ Dalam perkawinan banyak dilakukan antara pedagang Islam dengan putri-putri adipati. Dalam pernikahan, mempelai pria Islam (juga wanitanya) mengajukan syarat pengucapan kalimat syahadat sebagai sahnya pernikahan. Anak-anak yang dihasilkan dari pernikahan tersebut cenderung mengikuti agama orang tuanya yang Islam. Perkawinan antara saudagar Islam dengan anak-anak kaum bangsawan, raja, atau adipati menguntungkan perkembangan Islam. Status sosial, ekonomi, dan politik mertua-mertua mereka memungkinkan Islam melakukan penetrasi langsung ke jantung kekuasaan politik lokal (palace circle). Saat sudah berada di aras pusat kekuasaan politik, penerbitan kebijakan-kebijakan yang menguatkan penyebaran Islam mendapat prioritas dalam input, konversi, dan output kebijakan para sultan atau para adipatinya.

9 Tasawuf merupakan epistemologi Islam yang banyak menarik perhatian kalangan pribumi. Metodenya yang toleran, tidak mengakibatkan cultural shock signifikan, membuat banjir penganut Islam baru. Tasawuf cenderung tidak menciptakan posisi diametral Islam dengan budaya India ataupun tradisi lokal yang dipraktekkan kalangan pribumi. Tokoh-tokoh tasawuf Hamzah Fansuri, Syamsudin Pasai, ataupun beberapa tokoh Wali Sanga (termasuk juga Syekh Siti Jenar) mengambil posisi kunci dalam metode penyebaran ini. Lewat tasawuf pula, bentuk Islam yang diperkenalkan menunjukkan persamaan dengan alam pikiran orang-orang Jawa-Hindu, çiwa, dan Buddha. Akibatnya, Islam tidak dipandang sesuatu yang sama sekali asing bagi kalangan pribumi.

${ }^{10}$ Sebelum Islam masuk, Indonesia dikenal sebagai basis pendidikan agama Buddha, khususnya perguruan Nalendra di Sumatera Selatan. Pecantrikan dan Mandala adalah sekolah tempat para penuntut ilmu di kalangan penduduk pra Islam. Setelah Islam masuk, peran Pecantrikan dan Mandala tersebut diambil alih lalu diberi muatan Islam dalam kurikulumnya. Kini pesantren (Islam) berlaku sebagai pusat pembinaan guru agama, kiai, dan ulama. Selesai pendidikan, lulusan kembali ke kampung dan desa masingmasing untuk menjadi tokoh agama atau mendirikan pesantren sendiri. Misalnya Raden Rahmat (Sunan Ampel) yang mendirikan pesantren di Ampel Denta. Selain itu, pesantren yang didirikan Sunan Giri menjadi terkenal hingga Maluku dan menyebabkan penduduk Maluku (khususnya wilayah Hitu) datang berguru pada Sunan Giri. Atau, para kiai dari Giri diundang 
seni $^{11}$ dan tawaran pembentukan masyarakat egalitarian ${ }^{12}$ dalam strata sosial dan lain-lain. ${ }^{13}$

Michael C. William menuturkan, secara keseluruhan Banten sejak abad ke 19 secara ekonomis dan politis memang terpencil. ${ }^{14}$ Ketika Islam masuk di Banten, masyarakatnya sudah mempunyai kebudayaan yang amat kuat. Jika ditelisik lebih jauh, sebelum Islam berkembang di Banten, masyarakat Banten masih hidup dalam tata cara kehidupan tradisi prasejarah dan dalam abad-abad permulaan masehi ketika agama Hindu berkembang di Indonesia. Namun setelah

mengajar ke Hitu. Biasanya, yang diundang menjadi khatib, modin, atau kadi masyarakat Hitu dan diberi upah cengkih.

${ }^{11}$ Seni punya peran signifikan dalam penyebaran Islam. Orang Indonesia sebelum kedatangan Islam terkenal sebagai seniman-seniman jenius yang punya kemashuran tinggi. Lewat seni, Islam mampu menjangkau segmen lebih luas masyarakat pribumi, termasuk para elitnya. Sunan Kalijaga misalnya, menggunakan wayang sebagai cara dakwah baik atas penduduk biasa maupun elit sosial. Sunan Bonang menggunakan gamelan dalam melantunkan syair-syair keagamaan. Ini belum termasuk tokoh-tokoh lain yang mengadaptasi seni kerajinan lokal dan India yang diberi muatan Islam.

${ }^{12}$ Egalitarianisme akhirnya menempati posisi kunci. Problem utama di budaya sebelumnya adalah stratifikasi sosial berdasarkan kasta. Meski tidak terlampau ketat, Hindu di Indonesia sedikit banyak dipengaruhi terbentuknya kasta sosial seperti Brahmana, Ksatria, Waisya, Sudra dan Paria. Masyarakat biasa kurang leluasa dengan sistem ini oleh sebab mengakibatkan sejumlah keterbatasan dalam hal pergaulan dan perkawinan. Lalu, Islam datang dan tidak mengenal stratifikasi sosial. Mudah dipahami, orang-orang Indonesia (terutama dari kasta bawah) yang hendak bebas merespon baik agama baru ini.

${ }^{13}$ Petunjuk tegas munculnya Islam pertama di nusantara adalah nisan Sultan Sulaiman bin Abdullah bin al-Basir yang wafat tahun 608H atau 1211 M, di pemakaman Lamreh, Sumatera bagian Utara. Nisan ini menunjukkan adanya kerajaan Islam pertama nusantara. Lihat, Marwati Djoened Poesponegoro dan Nugroho Notosusanto, Sejarah Nasional Indonesia III: Jaman Pertumbuhan dan Perkembangan Kerajaan Islam di Indonesia, Edisi Pemutakhiran (Jakarta: Balai Pustaka, 2008), h.169-75.

${ }^{14}$ Michael C. William "Banten:Utang Padi Dibayar Padi, Utang Darah Dibayar Darah" dalam buku Audrey Kahin Pergolakan pada Daerah Awal Kemerdekaan, (Jakarta: Graffiti Pers, 1990). 
masuknya peradaban, Banten justru tercatat pernah menjadi kerajaan Islam.

Islamisasi budaya yang terjadi di Banten melahirkan sederet budaya khas Banten, di antaranya debus dan dzikir mulud. Studi terhadap seni budaya debus dan dzikir mulud di Banten akan didekati dengan pendekatan ${ }^{15}$ interdisipliner $^{16}$ melalui kajian sosiologis, ${ }^{17}$ dan sejarah. $^{18}$ Dalam

${ }^{15}$ Pendekatan adalah cara pandang atau paradigma yang terdapat dalam suatu bidang ilmu yang selanjutnya digunakan dalam memahami agama. Dalam hal ini adalah agama Islam. Islam dapat dilihat dalam beberapa aspek yang sesuai dengan paradigmanya. Baca, M. Yatimin Abdullah, Studi Islam Kontemporer, (Jakarta: Amzah, 2006), h. 58.

${ }^{16}$ Pendekatan interdisliner yang dimaksud disini adalah kajian dengan menggunakan sejumlah pendekatan atau sudut pandang (perspektif). Dalam studi misalnya menggunakan pendektan sosiologis, historis dan normatif secara bersamaan. Pentingnya penggunaan pendekatan ini semakin dirasakan dari keterbatasan dari hasil-hasil penelitian yang hanya menggunakan satu pendekatan tertentu.

${ }^{17}$ Sosiologi adalah ilmu tentang kemasyarakatan, ilmu yang mempelajari segala sesuatu yang berhubungan dengan masyarakat. Sosiologi didefinisikan secara luas sebagai bidang penelitian yang tujuannya meningkatkan pengetahuan melalui pengamatan dasar manusia,dan pola organisasi serta hukumnya.Sosiologi dapat juga diartikan sebagai suatu ilmu yang menggambarkan tentang keadaan masyarakat lengkap dengan struktur, lapisan serta berbagai gejala sosial lainnya yang saling berkaitan. Selanjutnya sosiologi digunakan sebagai salah satu pendekatan dalam studi islam yang mencoba untuk memahami islam dari aspek sosial yang berkembang dimasyarakat, sehingga pendidikan dengan pendekatan sosiologis dapat diartikan sebagai sebuah studi yang memanfaatkan sosiologi untuk menjelaskan konsep pendidikan dan memecahkan berbagai problema yang dihadapinya. Pendidikan menurut pendekatan sosiologi ini dipandang sebagai salah satu konstruksi sosial atau diciptakan oleh interaksi sosial. Pendekatan sosiologi dalam praktiknya, bukan saja digunakan dalam memahami masalahmasalah pendidikan, melainkan juga dalam memahami bidang lainnya, seperti agama sehingga munculah studi tentang sosiologi agama. Baca, Abuddin Nata, Пmu Pendidikan Islam dengan Pendekatan Multidisipliner, Normatif Perenialis, Sejarah, Filsafat, Psikologi, Sosiologi, Manajemen, Teknologi, Informasi, Kebudayaan, Politik, Hukum, Jakarta: Rajawali Press, 2009, h. 203.

${ }^{18}$ Dalam bahasa Arab, kata sejarah disebut tarikh yang secara harfiah berarti ketentuan waktu, dan secara istilah berarti keterangan yang telah terjadi pada masa lampau / masa yang masih ada. Dalam bahasa Inggris, kata sejarah merupakan terjemahan dari kata history yang secara harfiah diartikan 
menganalisis data, digunakan analisis isi (content analysis). Analisis ini merupakan analisis tentang isi pesan suatu komunikasi dan mengolahnya, ${ }^{19}$ dalam artian menangkap pesan yang tersirat dari satu atau beberapa pernyataannya.

\section{B. Islam, Budaya dan ke-Banten-an}

Kerajaan Islam di Banten saat itu lebih dikenal oleh masyarakat Banten dan sekitarnya dengan sebutan Kesultanan Banten. Kesultanan Banten telah mencapai masa kejayaannya dimasa lalu dan telah berhasil merubah wajah sebagian besar masyarakat Banten. Pengaruh yang besar diberikan oleh Islam melalui kesultanan dan para ulama serta mubaligh Islam di Banten, tidak dapat disangsikan lagi dan penyebarannya melalui jalur politik, pendidikan, kebudayaan dan ekonomi di masa itu.

\section{Dalam perjalanan sejarahnya, menurut Hoesein Djajadiningrat, ${ }^{20}$ bahwa penyebaran Islam di Banten ${ }^{21}$}

the past experience of mankind, yakni pengalaman umat manusia di masa lampau. Abuddin Nata, Metodologi Studi Islam, (Jakarta: Raja Grafindo Persada, 2006), h. 46.

${ }^{19}$ Imam Suprayogo dan Tobroni, Metode Penelitian Sosial-Agama (Bandung: Remaja Rosda Karya, 2001), 71.

${ }^{20}$ Prof. Dr. P.A. Hoesein Djajadiningrat adalah putra bupati Serang, pernah menjadi anggota Raad van Indie (semacam dewan penasehat) di zaman Belanda, serta kepala Shumubu (semacam departemen agama) di zaman Jepang. Dia merupakan anggota Dokuritsu Junbi Cosakai yang menyusun UUD 1945. Lihat, Nia Kurnia Solihat Irfan, "Tinjauan Kritis Tentang Sejarah Banten”, Resensi Buku, Majalah Tempo, 1 Oktober 1983. Buka pula, http://irfananshory. blogspot.com/2007/04/resensi-buku-di-majalah-tempo.html

${ }^{21}$ Berkaitan dengan sejarah Banten dari masa ke masa baca lebih lanjut: Hasan Muarif Ambary, Halwany Michrob, John N. Miksic, Katalogus Koleksi Data Arkeologi Banten, (Jakarta: Depdikbud, 1988); Hamka, Sejarah Ummat Islam, (Jakarta: Bulan Bintang, 1976); Muhammad Ismail, Petunjuk Jalan dan Keterangan Bekas Kerajaan Kesultanan Banten, (Serang: Saudara, 1983); Halwany Michrob, Pemugaran dan Penelitian Arkeologi sebagai Sumbangan Data bagi Perkembangan Sejarah Kerajaan Islam Banten, Skripsi, Jakarta: IPPM, 1981; Halwany Michrob dan Mudjahid Chudari, Catatan Masalalu Banten, (Serang: 
dilakukan oleh Syarif Hidayatullah, pada tahun 1525 M dan 1526 M. Pada tahun 1475 M, beliau menikah dengan adik bupati Banten yang bernama Nhay Kawunganten, dua tahun kemudian lahirlah anak perempuan pertama yang diberi nama Ratu Winahon dan pada tahun berikutnya lahir pula pangeran Hasanuddin. Setelah Pangeran Hasanuddin menginjak dewasa, Syarif Hidayatullah pergi ke Cirebon mengemban tugas sebagai Tumenggung di sana. Adapun tugasnya dalam penyebaran Islam di Banten diserahkan kepada Pangeran Hasanuddin, di dalam usaha penyebaran agama Islam ini Pangeran Hasanuddin berkeliling dari daerah ke daerah seperti dari G. Pulosari, G. Karang bahkan sampai ke Pulau Panaitan di Ujung Kulon. ${ }^{22}$ Sehingga berangsur-angsur penduduk Banten Utara memeluk agama Islam. $^{23}$

Setelah kesultanan Banten berakhir, maka sekarang tinggallah peninggalan sejarah berupa bekas istana kerajaan dan beberapa bangunan lain seperti; Keraton Surosowan, Keraton Kaibon, Masjid Agung dan Menara Banten, Masjid Pacinan Tinggi, Masjid Kasunyatan, Masjid Caringin, Gedung Timayah, makam-makam sultan Banten dan banyak lagi yang lainnya. Bangunan-bangunan itu tidak terlepas dari pengaruh religius (Hinduisme dan Islam), serta terjadinya akulturasi negara-negara lain seperti; Belanda, Cina, dan Gujarat. Dari telaah penyebaran Islam ke nusantara dan peninggalanpeninggalan budaya di atas, satu di antara yang banyak berpengaruh adalah melalui jalur seni dan budaya, termasuk juga penyebaran Islam dan budaya ke Banten.

Saudara, 1993); Uka Tjandrasasmita, (Ed.), Sejarah Nasional Indonesia, (Jakarta: Depdikbud, 1975), Uka Tjandrasasmita, Sultan Ageng Tirtayasa Musuh Besar Kompeni Belanda, (Jakarta: Yayasan Nusalarang, 1967) dll.

${ }^{22}$ Baca, P.A. Hoesein Djajadiningrat, Tinjauan Kritis tentang Sedjarah Banten, (Jakarta: Djambatan, 1983), h.34.

${ }^{23}$ Baca lebih lanjut, Tb.G. Roesjan, Sejarah Banten, (Jakarta: Arief, 1954), h. 10 . 
Secara geografis, Banten adalah daerah yang berada paling barat dari pulau Jawa, dikenal sebagai kota Santri dan kota Jawara ${ }^{24}$ atau Pendekar. ${ }^{25}$ Masyarakat Islam Banten, dalam tradisi keislaman di Indonesia pada masa lalu, dikenal lebih sadar-diri dibandingkan dengan daerah lainnya di Jawa. ${ }^{26}$ Bukan hanya itu saja, orang Banten yang pernah menjadi pusat kerajaan Islam juga dikenal penduduknya sangat taat beragama. ${ }^{27}$

Dalam tinjauan sejarah mungkin ada perbedaan pendapat mengenai kapan Banten itu dimulai. Tetapi ada satu hal, melihat kebudayaan Banten boleh jadi dari dimulainya masa Kesultanan Banten, Maulana Hasanuddin (1552).

${ }^{24}$ Jawara kerap kali disebut sebagai pembuat keonaran dan bandit. Makna jawara bergeser dan terkontaminasi dengan hal negatif terjadi pada abad 19. Pemerintah kolonial Belanda membentuk stigma negatif kepada para pejuang dari kalangan pendekar silat dan kaum ulama. Belanda mengecap semua kaum jawara sebagai bandit. Gerakan sosial dan perlawanan melawan penjajahan asing dianggap sebagai onsluten (keonaran), ongergeldheden (pemberontakan), complot (komplotan), woelingen (kekacauan), dan onrust (ketidak amanan). Lebih lanjut lihat, Faisal Fadilla Noorikhsan, "Menapaki Jejak Jawara Banten”, diakses dari http://salmanitb.com /2012/05/ menapakijejak-jawara-Banten. Pembuat keonaran dan bandit. Makna jawara bergeser dan terkontaminasi dengan hal negatif terjadi pada abad 19. Pemerintah kolonial Belanda membentuk stigma negatif kepada para pejuang dari kalangan pendekar silat dan kaum ulama. Belanda mengecap semua kaum jawara sebagai bandit. Buka, Faisal Fadilla Noorikhsan, "Menapaki Jejak Jawara Banten”, diakses dari http://salmanitb.com /2012/05/ menapaki-jejakjawara Banten.

${ }^{25}$ Baca lebih lanjut, Sartono Kartodirdjo, Pemberontakan Petani Banten 1888, (Jakarta: Pustaka Jaya, 1984), h. 84; baca pula, M.A. Tihami, "Kepemimpinan Kyai dan Jawara di Banten," Tesis S2 Universitas Indonesia, 1992; lihat pula, HMA. Tihami, Kepimpinan Kiyai di Banten Studi Tentang Agama dan Magic di Desa Pesanggrahan Serang Banten, (Serang : P3M STAIN Serang, 1999); lihat pula, Mohammad Hudaeri dkk., "Tasbih dan Golok: Studi tentang Kharisma Kiai dan Jawara di Banten”, ISTIQRA, Jurnal Penelitian Dipertais, Kemenag RI, Ringkasan Laporan Hasil Penelitian Kompetitif Tahun 2002.

${ }^{26}$ Martin van Bruinessen, Kitab Kuning, Pesantren dan Tarekat: TradisiTradisi Islam di Indonesia, cet. III, (Bandung: Mizan, 1999), h. 246.

${ }^{27}$ Baca lebih lanjut, Zamakhsyari Dhofier, Tradisi Pesantren: Studi tentang Pandangan Hidup Kyai, (Jakarta: LP3ES, 1985). 
Alasannya, pada waktu itulah terjadi peristiwa kultural yang besar dan radikal sebagai akibat dari kekuasaan Sultan yang Islam..$^{28}$

Sebagian ahli kebudayaan memandang bahwa kecenderungan untuk berbudaya merupakan dinamik ilahi. Di dalam Kamus Besar Bahasa Indonesia, ${ }^{29}$ disebutkan bahwa: "budaya" adalah pikiran, akal budi, adat istiadat. Sedang "kebudayaan" adalah hasil kegiatan dan penciptaan batin (akal budi) manusia, seperti kepercayaan, kesenian dan adat istiadat. Ahli sosiologi mengartikan kebudayaan dengan keseluruhan kecakapan (adat, akhlak, kesenian, ilmu dll). Sedang ahli sejarah mengartikan kebudaaan sebagai warisan atau tradisi. Bahkan ahli Antropologi melihat kebudayaan sebagai tata hidup, way of life, dan kelakuan.

Definisi-definisi tersebut menunjukkan bahwa jangkauan kebudayaan sangatlah luas. Untuk memudahkan pembahasan, dari banyaknya cakupan kebudayaan, paling tidak dibagi menjadi lima aspek : kehidupan spritual, bahasa dan kesusastraan, kesenian, sejarah, dan ilmu pengetahuan. Aspek kehidupan spritual, mencakup kebudayaan fisik, seperti sarana (candi, patung nenek moyang, arsitektur), peralatan (pakaian, makanan, alat-alat upacara). Juga mencakup sistem sosial, seperti upacara-upacara (kelahiran, pernikahan, kematian).

Dari keterangan-keterangan di atas, seni budaya Banten merupakan kesenian peninggalan sebelum Islam dan dipadu atau diwarnai dengan agama Islam. Misalnya arsitektur masjid dengan tiga tingkat sebagai simbolisasi Iman, Islam, Ihsan, atau Syari'at, Tharekat, Hakekat. Mengenai kesenian lain, ada pula yang teridentifikasi kesenian lama (dulu) yang belum berubah,

${ }^{28}$ Baca lebih lanjut, Djajadiningrat, Tinjauan Kritis, h. 144; Muhammad Ismail, h. 35.

${ }^{29}$ Tim Penyusun Kamus Pusat Pembinaan dan Pengembangan Bahasa DEPDIKBUD, Kamus Besar Bahasa Indonesia, (Jakarta: balai Pustaka, 1996), h. 149. 
kecuali mungkin kemasannya. Dalam catatan Wikipedia, potensi dan kekhasan budaya masyarakat Banten, antara lain seni bela diri pencak silat, Debus, Rudad, Umbruk, Tari Saman, Tari Topeng, Tari Cokek, Dog-Dog, Palingtung, dan Lojor. Di samping itu juga terdapat peninggalan warisan leluhur antara lain Masjid Agung Banten Lama, Makam Keramat Panjang, dan masih banyak peninggalan lainnya. ${ }^{30}$

\section{Memotret Kebudaya Banten}

M.A. Tihami dalam tulisnnya "Potret Budaya Dulu, Kini dan Nanti”, menyebutkan ada 25 seni yang ada di Banten yaitu: Seni debus surosowan, seni debus pusaka Banten, seni rudat, seni terbang gede, seni patingtung, seni wayang golek, seni saman, seni sulap-kebatinan, seni angklung buhun, seni beluk, seni wawacan syekh, seni mawalan, seni kasidahan, seni gambus, seni reog, seni calung, seni marhaban, seni dzikir mulud, seni terbang genjring, seni bendrong lesung, seni gacle, seni buka pintu, seni wayang kulit, seni tari wewe, dan seni adu bedug. ${ }^{31}$ Bahkan, dalam sumber lain, melengkapi apa yang telah disebutkan sebelumnya, di Banten ditemukan ada jenisjenis tari yaitu: angklung buhun, debus, dzikir saman (dzikir mulud), kesenian buaya putih, pantung bambo, dan rampak bedug. ${ }^{32}$ Dalam pengamatan peneliti bukan hanya 25 seperti yang disebutkan MA. Tihami, tapi masih banyak lagi seni budaya Banten yang tidak disebutkan yaitu: ${ }^{33}$ debus, angklung buhun, dog-dog lojor, beluk, patingtung, rudat, dzikir saman, terbang gede, bedug, ubrug, qasidah, marhaba raqbi, gambang kromong, tari cokek, tayuban, yalail, rengkong, gemyung,

${ }^{30}$ Wikipedia Bahasa Indonesia, "Banten” diakses dari /wiki/Banten.

${ }^{31}$ M.A. Tihami, "Potret Budaya Dulu, Kini dan Nanti", diakses dari http:// Bantenologi.org/index.php?option=com_content\&view=article\&id=83:potretbudaya-Banten-dulu-kini-dan-nanti\&catid=1:latest-news\&Itemid=50

${ }^{32}$ Humay MD, “10 Jenis Tarian Daerah Banten”, diakses dari http:// humaysmash.blogspot.com/2012/12/10-jenis-tarian-daerah-Banten.html.

${ }^{33}$ Tashrief Adrianto, "Ikhtisar Seni Budaya Banten", diakses dari /2009/05/ikhtisar-seni-budaya-Banten.html. 
wayang garing, seren taun, dan panjang mulud. Di antara banyaknya kesenian Banten yang disebutkan di atas, tulisan ini menyajikan dua seni budaya Banten, yaitu debus dan dzikir mulud.

Studi tentang debus dan dzikir mulud yang dikaitkan dengan seni budaya Islam lokal di Banten, termasuk di Indonesia, serta kajian seni budaya Banten termasuk masih jarang untuk tidak mengatakan langka. Kalaupun ada, masih sebatas kajian kecil masuk sub bab kajian tentang ke-Banten-an dan sejarah Banten.

Pertama, Uib Sholahuddin Al-Ayubi, Islam Dan Tradisi Lokal Banten (Studi Ritulitas Panjang Mulud di Serang Banten), Lembaga Penelitian IAIN SMH Banten, 2006. Kedua, MA. Tihami, Kepimpinan Kiyai di Banten Studi Tentang Agama dan Magic di Desa Pesanggrahan Serang Banten, Serang : P3M STAIN Serang, 1999. Ketiga, M.A. Tihami, "Kepemimpinan Kyai dan Jawara di Banten," Tesis S2 Universitas Indonesia, 1992. Keempat, Muhaimin AG, Islam Dalam Bingkai Budaya Lokal Potret dari Cirebon, Jakarta: P.T. Logos Wacana Ilmu, 2002. Kelima, Hasan Muarif Ambary, Halwany Michrob, John N. Miksic, Katalogus Koleksi Data Arkeologi Banten, Jakarta: Adrianto, Tashrief, "Ikhtisar Seni Budaya Banten”. Keenam, Anggaz, "Ilmu Debus" diakses dari http://anggaz.wordpress.com. Ketujuh, Ririn Astri, “Tradisi Maulid Nabi di berbagai daerah di Indonesia” diakses dari http://ririnastri.blogspot.com.

Ketujuh, Martin Van Bruinessen, Kitab Kuning, Pesantren dan Tarekat: Tradisi-Tradisi Islam di Indonesia, Bandung: Mizan, 1999. Ketujuh, Zamakhsyari Dhofier, Tradisi Pesantren: Studi tentang Pandangan Hidup Kyai, Jakarta: LP3ES, 1985. Kedelapan, P.A. Hoesein Djajadiningrat, Tinjauan Kritis tentang Sedjarah Banten, Jakarta: Djambatan, 1983. Kesembilan, Disbudpar, "Dzikir Saman”. Kesepuluh, Mohammad Hudaeri dkk., "Tasbih dan Golok: Studi tentang Kharisma Kiai dan Jawara di Banten”, 
Islam dan Budaya Di Banten:

ISTIQRA, Jurnal Penelitian Dipertais, Kemenag RI, Ringkasan Laporan Hasil Penelitian Kompetitif Tahun 2002.

Kesebelas, Lukman Hakim, Banten dalam Perjalanan Jurnalistik, Pandeglang : Banten Heritage, 2006. Keduabelas, Muhammad Ismail, Petunjuk Jalan dan Keterangan Bekas Kerajaan Kesultanan Banten, Serang: Saudara, 1983. Ketigabelas Sartono Kartodirdjo, Pemberontakan Petani Banten 1888, Jakarta: Pustaka Jaya, 1984, keempatbelas, Opan, “Tradisi Panjang Mulud, Warisan Budaya Kesultanan Banten”. Kelimabelas, Tb.G. Roesjan, Sejarah Banten, Jakarta: Arief, 1954. Keenambelas, Uka Tjandrasasmita, Sultan Ageng Tirtayasa Musuh Besar Kompeni Belanda, Jakarta: Yayasan Nusalarang, 1967. Keenambelas, Makmun Muzakki, “Tarekat dan Debus Rifaiyyah di Banten”, Skripsi Fakultas Sastra Universitas Indonesia, 1990.

Berdasarkan review terhadap beberapa laporan penelitian seperti telah penulis sebutkan di atas, sejatinya belum mencerminkan locus, fokus, dan orientasi atau pendekatan sebagaimana yang peneliti lakukan melalui studi ini. Penelitian mengenai aspek debus dan dzikir mulud di Banten sejauh ini belum ada yang melakukan. Penelitian ini merupakan sesuatu yang bisa jadi dianggap penelitian pertama yang mengangkat kajian debus dan dzikir mulud perspektif Islam budaya lokal. Di sinilah tergambar salah satu urgensi penelitian ini untuk mencari gambaran tentang budaya Banten yang terbingkai dalam budaya debus dan dzikir mulud sehingga Islam dan budaya dalam debus dan dzikir mulud dapat dimanfaatkan oleh masyarakat luas. Bukan hanya untuk dinikmati keindahannya, tapi semangat perjuanganpun akan mengiri sejarah lahirnya budaya tersebut.

Relasi antara Islam sebagai agama dengan adat dan budaya lokal sangat jelas dalam kajian antropologi agama. Dalam perspektif ini diyakini, bahwa agama merupakan penjelmaan dari sistem budaya. Berdasarkan teori ini, Islam 
sebagai agama samawi dianggap merupakan penjelmaan dari sistem budaya suatu masyarakat Muslim.

Debus adalah seni pertunjukan yang memperlihatkan permainan kekebalan tubuh. Debus menjadi salah satu bagian ragam seni budaya masyarakat Banten sehingga kesenian ini banyak digemari oleh masyarakat sebagai hiburan yang langka dan menarik di Banten. Debus berasal dari "dabus" yang artinya paku atau peniti, yakni suatu "permainan" dengan senjata tajam yang dengan keras ditikamkan ke tubuh para pemainnya. Di Banten ada beberapa macam debus, yakni debus al-Madad, Surosowan dan langitan. ${ }^{34}$

Dinamakan debus al-madad (artinya meminta bantuan atau pertolongan) karena para pemainnya setiap kali melakukan aksinya selalu mengucapkan kata-kata al-madad, yang seolah menggambarkan bahwa tindakan ini didasarkan atas pertolongan dari Allah SWT. Debus al-madad merupakan debus yang paling berat karena untuk melakukan permainan ini khalifahnya (pemimpin group) harus melakukan amalan yang sangat panjang dan berat. Amalan-amalan khalifah debus ini diambil dari tarekat Rifaiyah atau Qodariyah. Sehingga seseorang yang mendapat ijazah untuk menjadi khalifah dari permainan debus ini adalah mereka yang telah dianggap mampu atau lulus menempuh suatu perjalanan panjang dalam mengamalkan suatu do'a-do'a tertentu, melaksanakan puasa dan meditasi lama. ${ }^{35}$ Sedang Dzikir Mulud yaitu kesenian tradisional rakyat Banten yang menggunakan media gerak dan lagu (vokal) dan syair-syair yang dilantunkan mengagungkan Asma Allah dan pujian kepada Nabi Muhammad saw.

${ }^{34}$ Muhammad Hudaeri, "Peran Kiai dan Jawara”, diakses dari http://www. nimusinstitute.com/peran-kiayi-dan-jawara.

${ }^{35}$ Lebih jauh lihat Makmun Muzakki, “Tarekat dan Debus Rifaiyyah di Banten”, Skripsi Fakultas Sastra Universitas Indonesia, 1990. 


\section{Debus dan Dzikir Mulud: Islamisasi Budaya Khas Banten}

Debus lebih dikenal sebagai kesenian asli masyarakat Banten, yang berkembang kira-kira sejak abad ke 16-18. Debus dalam bahasa Arab yang berarti senjata tajam yang terbuat dari besi, mempunyai ujung yang runcing dan berbentuk sedikit bundar. Ada lagi pendapat bahwa debus berasal dari kata tembus. Dalam pespektif lain, ada lagi yang menyebutkan bahwa debus berasal dari kata gedebus, yaitu nama salah satu benda tajam yang digunakan dalam pertunjukan kekebalan tubuh. Benda tajam tersebut terbuat dari besi, dan digunakan untuk melukai diri sendiri. Oleh karena itu kata debus dapat diartikan sebagai tidak tembus. Debus adalah salah satu ilmu warisan leluhur yang cukup dikenal hingga kepelosok Nusantara. Bahkan oleh sedulur yang sudah diakui kepiawaiannya dalam keilmuan debus, atraksi memotong lidah, memotong anggota badan yang lain juga sering kali dipertontonkan baik dalam negeri hingga ke mancanegara. ${ }^{36}$

Debus merupakan kesenian asli masyarakat Banten yang diciptakan pada abad ke-16, yaitu tepatnya pada masa pemerintahan Sultan Maulana Hasanuddin (15321570), dalam rangka penyebaran agama Islam. Agama Islam diperkenalkan ke Banten oleh Sunan Gunung Jati, salah satu pendiri Kesultanan Cirebon, pada tahun 1520, dalam ekspedisi damainya bersamaan dengan penaklukan Sunda Kelapa ${ }^{37}$ Kemudian, ketika kekuasaan Banten dipegang oleh

${ }^{36}$ Ki Bayu, "Ilmu Ajaib Debus Banten", diakses dari http://kibayu. wordpress.com/2009/07/01/ilmu-ajaib-debus-ti-leluhur/

${ }^{37}$ Sebagian besar penduduk Banten berketurunan orang Jawa dan Cirebon. Dalam perjalanan waktu, penduduk ini berbaur dengan orangorang Sunda, Bugis, Melayu dan Lampung. Perbauran yang begitu dalam menyebabkan penduduk Banten memiliki perbedaan-perbedaan dalam hal bahasa dan adat istiadat dengan masyarakat asalnya. Begitu pula dalam hal penampilan fisik dan watak, orang Banten menunjukkan perbedaan yang nyata dengan orang Sunda, orang Jawa Tengah dan Jawa Timur. Di antara unsur-unsur yang membentuk kebudayaan mereka hampir tak terdapat ciri- 
Sultan Ageng Tirtayasa (1651-1682), debus difokuskan sebagai alat untuk membangkitkan semangat para pejuang dalam melawan penjajah Belanda. Apalagi, di masa pemerintahannya tengah terjadi ketegangan dengan kaum pendatang dari Eropa, terutama para pedagang Belanda yang tergabung dalam VOC. Kedatangan kaum kolonialis ini di satu sisi membangkitkan semangat jihad kaum muslimin Nusantara, namun di sisi lain membuat pendalaman akidah Islam tidak merata, yaitu terjadinya percampuran akidah dengan tradisi pra-Islam. Hal ini yang terdapat pada kesenian debus. ${ }^{38}$

Menurut catatan sejarah, Debus itu sendiri sebenarnya ada hubungannya dengan tarikat Rifaiah. Tarikat ini dibawa oleh Nurrudin Ar-Raniry ke Aceh pada abad 16. Tarikat ini ketika melakukan suatu ritual sedang dalam kondisi epiphany (kegembiraan yang tak terhingga karena "bertatap muka" dengan Tuhan), mereka kerap menghantamkam berbagai benda tajam ke tubuh mereka. Filosofi sederhananya adalah "la haula wala Quwwata illa billah al-'aliyy al-adzhim" atau tiada daya upaya melainkan karena Allah semata. Jadi kalau Allah tidak mengijinkan pisau, golok, parang atau peluru sekalipun melukai mereka, maka mereka tak akan terluka. Pada kelanjutannya, tarikat ini sampai ke daerah Minang dan di Minang pun dikenal istilah Dabuih. Keyakinan kepada Allah model inilah yang menjadikan debus hingga saat ini masih terus dikenal bahkan menjadi warisan budaya.

Berkenaan dengan hal di atas yang mengungkap akar sejarah berawalnya kesenian debus yang menjadi ciri khas kesenian dari masyarakat tanah Banten, dari keterangan sebelumnya paling tidak ada 3 versi yang mengerucut: versi

ciri peradaban Hindu-Jawa. Karena Islam mengalami penetrasi yang sangat dalam pada masyarakat Banten. Lihat, Mohamad Hudaeri dkk., "Tasbih dan Golok", Jurnal Istiqra, Dipertais, Kemenag RI, diakses dari http://www. ditpertais.net/istiqro/ist02-04.asp.

${ }^{38}$ Anggaz, "Ilmu Debus" diakses dari http://anggaz.wordpress.com |2011/05/07/ilmu-debus-2/ 
pertama dari berawalnya kesenian debus, yakni diciptakan pada abad 16 pada masa pemerintahan Sultan Maulana (15321570 Masehi), sebagai salah satu cara yang dilakukan untuk menyebarkan ajaran agama islam. Versi kedua menyebutkan bahwa kesenian debus sebenarnya berasal dari daerah di Timur Tengah yang bernama Al-Madad, yang kemudian masuk ke tanah Banten pada abad 13 Masehi, melalui ulama penyebar agama Islam dari Timur Tengah yang menjadikan kesenian debus sebagai salah satu cara untuk menyebarkan ajaran agama Islam. Versi ketiga sendiri menyebutkan bahwa kesenian debus berasal dari ajaran tarekat Rifa'iyah Nurrudin al-Raniry di Aceh, yang kemudian masuk ke Banten pada abad 16 Masehi melalui para pengawal dari pahlawan perjuangan Cut Nyak Dien, yang pada waktu itu diasingkan oleh penjajah belanda di Sumedang, hingga akhirnya di antara pengawal tersebut ada yang pergi sampai ke wilayah Banten dan kemudian memperkenalkan dan mengajarkan debus pada masyarakat setempat. ${ }^{39}$

Kalau zaman dahulu, ilmu debus dijadikan sarana perisai untuk melawan senjata api para penjajah dan dijadikan pengobatan apabila ada yang terluka karena sabetan pedang atau terjangan peluru. Namun kini seiring perkembangan zaman, ilmu langka ini dijadikan komoditi hiburan dan seni budaya. Dengan alat inilah para pemain debus dilukai, dan biasanya tidak dapat ditembus walaupun debus itu dipukul berkali kali oleh orang lain. Atraksi kekebalan badan ini merupakan variasi lain yang ada dipertunjukan debus. Antara lain, menusuk perut dengan benda tajam atau tombak, mengiris tubuh dengan golok sampai terluka maupun tanpa luka, makan bara api, memasukkan jarum yang panjang ke lidah, kulit, pipi sampai tembus dan tidak terluka. Mengiris anggota tubuh sampai terluka dan mengeluarkan darah tetapi

39 "Mengenal Kesenian Debus dari Banten, Indonesia", diakses dari http://info-info-umum.blogspot.com/2012/03/mengenal-kesenian-debus-dari. html 
dapat disembuhkan pada seketika itu juga, menyiram tubuh dengan air keras sampai pakaian yang melekat dibadan hancur, mengunyah beling/serpihan kaca, membakar tubuh dan masih banyak lagi atraksi yang mereka lakukan.

Dalam melakukan atraksi ini setiap pemain mempunyai syarat-syarat yang berat, sebelum pentas mereka melakukan ritual-ritual yang diberikan oleh guru mereka. Biasanya dilakukan 1-2 minggu sebelum ritual dilakukan. Selain itu mereka juga dituntut mempunyai iman yang kuat dan harus yakin dengan ajaran Islam. Pantangan bagi pemain debus adalah tidak boleh minum minuman keras, main judi, bermain wanita, atau mencuri. Dan pemain juga harus yakin dan tidak ragu-ragu dalam melaksanakan tindakan tersebut, pelanggaran yang dilakukan oleh seorang pemain bisa sangat membahayakan jiwa pemain tersebut.

Selain debus, warisan budaya yang cukup kental dengan orang Banten adalah dzikir mulud. Kalau ada anggapan bahwa debus adalah sangat kental dengan nuansa magisnya, atau bahkan tidak jarang dianggap sebagai perbuatan yang erat kaitannya dengan sistem perdukunan, klenik, alam ghaib, dan bahkan dekat sekali dengan nuansa syirik. Maka, dzikir mulud berbalik 100 persen dengan debus. Namun ditinjau dari sisi seninya, sama-sama memiliki keunikan dan kekhasan tersendiri yang menggambarkan peradaban masyarakat Banten yang kental dengan nuansa Islam sebagai hasil akulturasi dengan budaya lokal dan pendatang.

Pada mulanya, istilah maulid atau mulud dipergunakan bagi peringatan dan perayaan hari jadi seorang yang dianggap suci, laki-laki atau perempuan, muslim, Kristen atau Yahudi yang sudah meninggal. Namun istilah ini kemudian populer dipergunakan bagi kelahiran Nabi Muhammad. Perayaan Maulid Nabi Muhammad saw. pertama kali dilakukan pada zaman Fathimiyyah (dinasti yang didirikan pada $920 \mathrm{M}$ ) yang bermadzhab Syi'ah. Sedangkan Muhammad Abdus Salam 
menyatakan bahwa maulid Nabi itu diada-adakan oleh kaum sufi al-akkalun (cari makan). ${ }^{40}$ Dikalangan sebagian kaum muslimin, istilah yang dipergunakan untuk perayaan itu sangat beragam. Di Mesir acara ini disebut Maulid. Di Tunisia, istilah yang dipakai adalah Zardah, sedangkan di negara Arab lainnya digunakan istilah Mausim. Di Sudan disebut Huliyyah. Hanya istilah Huliyyah ini dipergunakan dalam rangka memperingati ulang tahun kematian, dan bukan ulang tahun kelahiran mereka, yaitu pendiri tarekat-tarekat sufi.

Kemudian dilihat dari aspek ketetapan waktu penyelenggaraan, cara atau bentuk upacara, ternyata perayaan dalam rangka memperingati "orang suci" itu pun sangat beragam. Banyak "maulid" bagi "orang-orang suci" ditetapkan pada hari-hari kelahiran mereka menurut kalender Hijriah. Namun tidak sedikit tanggal maulid ditetapkan menurut kalender Syamsiah (Masehi). Disamping itu, perayaan tersebut dapat berubah menurut kondisi-kondisi historis dan sosial. seperti maulid Ahmad al-Badhawi di Mesir yang ditetapkan atas dasar keyakinan para pemujanya, bukan atas hari kelahiran yang sesungguhnya.

Sebagian ahli sejarah berpendapat bahwa fenomena maulid berakar dari tradisi-tradisi kuno, seperti yang berlangsung di Mesir, untuk menghormati dewa-dewa setiap tahun pada saat panen, sementara kuil-kuil menyusun berbagai prosesi serta perayaan yang rumit. Sebagian ahli sejarah lainnnya merunut maulid dari pengaruh Pharisaisme (sebuah sekte Yahudi kuno) dan perayaan kaum Yahudi pada masa Yahudi awal serta masa Kristen awal. Sedangkan bentuk modern maulid berakar dari tradisi sufi dan atau syi'ah yang muncul dari kawasan Maghribi (Maroko) dan Mesopotamia dan berkembang di Mekkah yang identik dengan praktik-

${ }^{40}$ Muhammad bin 'Abdus Salam Khodr Al-Syaqiriy, Al-Sunan wal Mubtada'at Al-Muta'alliqoh Bil Adzkari wa al-Sholawat, (Bairut: Darul Fikr, ttp.), h. 138-140. 
praktik serupa dikalangan masyarakat Kristen dan Yahudi di Timur Tengah. ${ }^{41}$

Pada perkembangan selanjutnya, di kalangan sebagian muslim perayaan hari jadi itu bukan saja ditujukan untuk memperingati Nabi Muhammad dan “orang saleh”, namun bagi berbagai peristiwa yang dianggap penting oleh masingmasing, seperti hari kelahiran dan kematian, berdirinya suatu golongan atau organisasi, hari kemenangan golongan, kemerdekaan dari penindasan golongan lain dan sebagainya. Istilah yang dipergunakan untuk peringatan dan perayaan itu pun menjadi beragam. Ada yang menyebut milad, dies natalies, ulang tahun, bahkan "syukuran”. Di kalangan Yahudi pun, istilah yang dipergunakan untuk peringatan dan perayaan “orang saleh” juga sangat beragam, namun pada umumnya ditujukan bagi berbagai peristiwa yang dialami oleh Nabi Musa dan Bani Israil.

Banten begitu kental dengan budaya Islam. Salah satunya adalah Dzikir Mulud ${ }^{42}$ atau yang dikenal pula

${ }^{41}$ Lihat, John L Esposito, Ensiklopedi Oxford: Dunia Islam Modern, (Jakarta: Djambatan, 2002), Jilid. 3, h. 75-76; lihat pula, Jilid. 4, h. 22-24 dan Jilid. 5, h. 228-229.

${ }^{42}$ Kata mulud seakar dengan Maulid, mulud, milad, dan semakna dengan kata natal. Kesemuanya memiliki pengertian yang sama yaitu hari lahir. Maulid, mulud, dan milad adalah bahasa Indonesia yang diserap dari bahasa Arab. Sedang kata mulud adalah bahasa khas Banten yang diserap dari bahasa Arab, sebagaimana kata natal yang sudah menjadi bahasa Indonesia yang diserap dari bahasa Latin. Sekalipun pengertian kelima kata tersebut di atas sama yaitu hari lahir, tetapi pemakaiannya tetap berbeda. Kata maulid, mulud, dan mulud digunakan untuk istilah peringatan hari lahir Nabi Muhammad, sehingga sering tertulis maulidunnabi atau maulidurrasul. Sedang kata milad sering di kaitkan dengan hari ulang tahun seseorang atau organisasi. Dan kata natal sendiri merujuk pada peringatan hari lahir Isa al-Masih, atau orang Kristen menyebutnya Yesus Kristus. Peneliti menyebut kata mulud bahasa khas Banten yang diserap dari bahasa Arab yaitu mulud, bisa jadi lidah orang Banten tidak nyaman atau bisa jadi tidak terbiasa dengan pelafalan mulud. Sehingga untuk mempermudah pengucapan mulud telah menjadi kebiasaan akhirnya lebih nyaman dengan pengucapan mulud. Peneliti di sini tidak menjustifikasi kata mulud ini hanya dialek orang Banten saja, karena bisa jadi suku lain 
dengan seni Saman. Seni Saman adalah kesenian tradisional rakyat Banten khususnya di Kabupaten Pandeglang yang menggunakan media gerak dan lagu (vokal) dan syair-syair yang dilantunkan mengagungkan asma Allah dan pujian kepada Nabi Muhammad saw. Tradisi di Banten sendiri, dzikir mulud biasasnya dimulai dengan alunan seni rebana yang membuka rangkaian perayaan. Rebana biasanya disandingkan dengan pembacaan salawat dan maulid Nabi yang kental nuansa keIslamannya. Perayaan semakin meriah dengan adanya arakarakan serta sajian aneka makanan. Demikian pula dengan pembakaran petasan, membuat suasana perayaan semakin terasa. Uniknya, semua itu dilakukan warga sekitar sambil berkeliling kampung. ${ }^{43}$

Sejarah zikir mulud sudah populer pada tahun 19271940. ${ }^{44}$ Berdasarkan literatur disebut dzikir Saman karena berkaitan arti Saman yaitu delapan dan dicetuskan pertama kali oleh Syekh Saman dari Aceh. Tari Saman berasal dari Kesultanan Banten yang dibawa para ulama pada abad 18 sebagai upacara keagamaan untuk memperingati hari kelahiran Nabi Muhammad saw pada bulan Mulud, namun dalam perkembangan selanjutnya dapat pula dilakukan pada upacara selametan khitanan, pernikahan atau selametan rumah. Pemain seni dzikir Saman berjumlah antara 26 sampai dengan 46 orang. 2 sampai 4 orang sebagai vokalis yang membacakan syair-syair Kitab. ${ }^{45}$ Kitab syair yang dibaca adalah syair-syair Barjanzi. Biasanya bacaan kitab Barjanzi lagu-lagunya tidak

menyebutnya sama. Akan tetapi dalam kajian ini, peneliti lebih menekankan bahwa kata mulud lahir dari lahjah orang Banten yang tereduksi dari bahasa aslinya yaitu bahasa Arab.

${ }^{43}$ Ririn Astri, "Tradisi Maulid Nabi di berbagai daerah di Indonesia" diakses dari http://ririnastri.blogspot.com/2011/02/tradisi-maulid-nabi-diberbagai-daerah.html.

${ }^{44}$ Lukman Hakim, Banten dalam Perjalanan Jurnalistik, (Pandeglang : Banten Heritage, 2006), h. 188=200.

${ }^{45}$ Humay MD, "10 Jenis Tarian Daerah Banten, “diakses dari http:// humaysmash.blogspot.com/2012/12/10-jenis-tarian-daerah-Banten.html. 
berubah sepanjang tahunnya. Dalam kitab ini memiliki 16 lagu-lagu. Ketika posisi duduk, lagu yang dibawakan pezikir adalah, assala, alfasa, tanakal, walidal, singkir, dzikrun, dan badat. Namun dalam posisi berdiri pezikir membacakan lagu hanya satu, yaitu : ya Nabi salam. Kemudian dilanjutkan lagi dengan posisi duduk yang kedua, dengan membacakan lagulagu terdiri dari 8 lagu, yaitu: ya Nur, Futur Kulwas, Ta'lam, Masmis, Wulidang, Talaubina Jalar nama, dan Habibun. ${ }^{46}$

Dalam pelaksanaannya, pezikir mulud kurang lebih selama 12 jam tidak berhenti berdzikirnya. Baru menjelang waktu salat dzuhur mereka beristirahat, yang dilanjutkan sampai salat ashar. ${ }^{47}$ Sementara 20 sampai 40 orang yang semuanya laki-laki mengimbangi lengkingan suara vokalis dengan saling bersahutan bersamaan (koor) sebagai alok. Pola permainan seni dzikir Saman dilakukan sehari penuh dengan tiga babakan, yaitu : Babakan Dzikir, Babakan Asroqol, dan Babakan Saman. ${ }^{48}$

Dalam rangka menambah semarak bulan Maulid, ${ }^{49}$ di Banten biasanya dzikir mulud atau seni Saman sering

\footnotetext{
${ }^{46}$ Lukman Hakim, Banten dalam Perjalanan Jurnalistik (Pandeglang : Banten Heritage, 2006), h. 201.

${ }^{47}$ Uib Sholahuddin Al Ayubi, "Panjang Mulud”, ringkasan penelitian Islam Dan Tradisi Lokal Banten: Studi Ritulitas Panjang Mulud di Serang Banten, Lembaga Penelitian IAIN SMH Banten, 2006.

${ }^{48}$ Disbudpar, “Dzikir Saman”, diakses dari http://www.disbudpar. Bantenprov.go.id/place/dzikir-saman.

${ }^{49}$ Maulid, mulud dan milad ketiganya berasal dari kata walada yalidu. Arti maulid adalah (1) tempat kelahiran atau (2) waktu kelahiran, karena maulid merupakan isim makan (tempat) atau isim zaman (waktu). Jadi, arti maulid Nabi adalah tempat atau waktu kelahiran Nabi. Dengan demikian, peringatan maulid Nabi dapat diartikan sebagai peringatan waktu kelahiran Nabi, atau secara umum disingkat dengan peringatan kelahiran Nabi. Sedangkan arti mulud adalah yang dilahirkan, merupakan isim maf'ul (objek). Jadi, arti mulud Nabi adalah yang dilahirkan (yaitu) Nabi Muhammad. Dengan demikian, peringatan mulud Nabi dapat diartikan dengan peringatan lahirnya Nabi, atau secara umum dipahami dengan peringatan kelahiran Nabi. Karena itu, istilah peringatan maulid nabi Muhammad SAW dan peringatan mulud Nabi Muhammad SAW kedua-duanya berarti peringatan kelahiran
} 
diperlombakan ${ }^{50}$ dengan hadiah yang menarik, baik antar kampung, kelurahan, kecamatan bahkan antara kota dan kabupaten. Penilaian diambil dari berbagai aspek seperti kekompakan olah vokal, seragam atau fashion, variasi dzikir, dan semangat para peserta. ${ }^{51}$

Di antara riuh dan gemuruhnya dzikir mulud itu, ada tradisi yang dikenal dengan panjang mulud. Tradisi panjang mulud, atau diistilahkan juga dengan ngeropok (ada juga dengan menyebut ngegropok $)^{52}$ panjang mulud. Tradisi

Nabi Muhammad SAW. sama saja. Peringatan maulid Nabi Muhammad SAW yang berarti peringatan kelahiran Nabi, tentu saja tidak sebatas memperingati kelahiran harinya saja. Makna yang lebih luas adalah kelahiran misinya sebagai rahmatan lil alamin. Karenanya, pengertian maulid Nabi Muhammad saw adalah untuk mengingat perjuangan Nabi dalam mengemban misinya. Mengingat sejarah perjuangan Nabi, mengingat akhlak Nabi. Tentu saja agar kita termotivasi untuk mencontohnya. Kemudian, arti milad adalah kelahiran (isim masdar, keterangan benda yang bersifat abstrak). Milad sering digunakan sebagai pengganti kata ulang tahun untuk orang atau organisasi. Dari uraian ini, maka tepatlah kiranya penggunaan kata mauled atau dalam dialek orang Banten mulud karena bukan hanya memperingati hari lahirnya, tetapi juga mengikuti semua yang dipernah dicontohkan oleh nabi Muhammad Saw.

${ }^{50}$ Kriteria lomba baca zikir ini, yaitu : memiliki kekompakan, suara yang indah, tajwid, dan qiroa'tnya. Kelompok juri diambil dan diundang dari kampung tetangga yang benar-benar memiliki kemampuan menilai dari hasil bacaan zikir tersebut. Baca, Uib Sholahuddin Al Ayubi, "Panjang Mulud”, ringkasan penelitian Islam Dan Tradisi Lokal Banten (Studi Ritulitas Panjang Mulud di Serang Banten), Lembaga Penelitian IAIN SMH Banten, 2006.

51 "Jombang Menjadi Juara Dzikir Mulud", diakses dari http:// Bantenpos-online.com/2012/02/08/jombang-juara-dzikir-mulud.

${ }^{52}$ Arti dari Ngeropok atau Ngegropok sendiri secara harfiah dapat diterjemahkan sebagai "Ngeriung” (kumpul-kumpul), atau juga ada yang menerjemahkan sebagai ajang rebutan dari "Panjang Mulud" itu sendiri. Sedangkan "Panjang Mulud" diartikan sebagai bentuk semacam sesajian, dalam masyarakat Jawa dikenal juga dengan "Gunung-Gunungan”. Panjang ini berisi berbagai macam makanan, sandang, atau berbagai benda lainnya. Panjang di bentuk seperti perahu, mobil, atau rumah, tetapi secara umum biasanya berbentuk perahu atau kapal, kemudian dihias, baik dari kertas warna, daun kelapa muda, atau kain-kain perca. Ciri khas dari isi Panjang adalah selalu ada telur rebus, kemudian dimasukkan ke dalam kantong terbuat dari kertas sebesar telur itu sendiri, kemudian digantung-gantungkan dalam rangkaian Panjang. 
panjang mulud konon diwariskan sejak jaman Sultan Ageng Tirtayasa. Panjang Mulud adalah tempat untuk mengangkut makanan, yang dibagikan pada perayaan Maulid atau hari lahir Nabi Muhammad SAW. Istilah atau penyebutan "panjang" ini pun berbagai makna, ada yang menterjemahkan bentuk dari sesajian itu sendiri karena banyaknya Panjang yang ditampilkan atau bentuk kapal yang panjang, ada juga yang mengartikan karena panjangnya prosesi yang harus dilalui dalam rangka memperingati Maulid Nabi Muhammad saw ini.

Panjang adalah tempat menaruh makanan dalam bentuk replika berbagai aneka, mulai dari bentuk kendaraan, masjid, perahu dan lainnya. Dari pemaknaan awal berkembang bukan hanya menaruh makanan, tapi merupakan memajangkan dan menyumbangkan hadiah berupa makanan yang khas, seperti nasi dan lauk pauknya. Panjang-panjang ini dihias bermacammacam bentuknya, seperti bentuk perahu, kapal terbang, ka'bah, kubah masjid, dan lain sebagainya. ${ }^{53}$ Biasanya replika ini disesuaikan dengan basis mata pencaharian masyarakatnya (misalnya untuk masyarakat pesisir berupa perahu), meski demikian tergantung juga dengan kreatifitas masyarakat yang membuatnya. Makanan yang ditempatkan dalam replika ini dihiasi dengan berbagai ornamen, seperti kertas warna-warni, uang, dan lain sebagainya. Panjang ini kemudian diarak keliling kampung/kota diiringi dengan musik tradisional rebana sampai kemudian arak-arakan ini berakhir di masjid, alun-alun atau kantor pemerintahan untuk disantap ramairamai dan dibagikan kepada warga bahkan juga diperebutkan oleh warga.

Kelahiran panjang mulud awalnya menjadi alat perjuangan melawan penjajahan kolonial sekitar tahun 1870 . Saat itu, sejumlah tokoh seperti Syaikh Nawawi, Ki Wasid,

${ }^{53}$ Lihat, Uib Sholahuddin al-Ayubi, "Panjang Mulud", ringkasan penelitian Islam Dan Tradisi Lokal Banten (Studi Ritulitas Panjang Mulud di Serang Banten), Lembaga Penelitian IAIN SMH Banten, 2006. 
dan Syaikh Abdul Karim mengumpulan dana perang untuk melawan kolonial dengan mengumpulkan barang-barang yang bisa dijual semisal kelapa dan buah lainnya dan berkeliling dari satu masjid ke masjid lainnya. Hasil penjualan itu selain digunakan untuk perang juga untuk keperluan lain seperti membangun masjid. ${ }^{54}$ Dari keterangan di atas, panjang mulud itu asal katanya adalah pajang mulud. Artinya, pameran kreasi masyarakat untuk sesembahan tapi sekarang berubah jadi panjang mulud.

Tradisi panjang mulud konon diwariskan sejak jaman Sultan Ageng Tirtayasa. Panjang mulud adalah tempat untuk mengangkut makanan, yang dibagikan pada perayaan Maulid atau hari lahir Nabi Muhammad SAW. Seiring dengan berjalannya waktu, bentuk Panjang Mulud kini juga mengikuti perkembangan budaya populer. "Apapun hasil kreasi seni ini tak diharamkan, selama mengikuti koridor," kata Ardi salah satu peserta perayaan panjang mulud, saat diminta tanggapannya terkait puncak tradisi keagamaan di Serang tersebut. ${ }^{55}$ Dari telaah di atas, entitas debus dan dzikir mulud dalam masyarakat Banten memiliki pengaruh yang melewati batas-batas geografis karena kharisma yang dimilikinya.

\section{E. Penutup}

Islam dan budaya lokal sampai saat ini masih eksis di masyarakat. Bahkan, istilah islamisasi budaya kian marak di hampir setiap daerah, termasuk di Banten. Tradisi debus dan dzikir mulud mengejawantahkan transmisi budaya sekaligus islamisasi budaya. Hal ini juga membuktikan tradisi klasik baik Hindu, Budha dan bahkan aliran kepercayaan turut memengaruhi transmisi budaya yang ada dan berkembang

54 “Arak-arakan Mauled Meriah”, diakses dari http:|/Bantenposonline. com/2012/02/06/arak-arakan-maulid-meriah/

${ }^{55}$ Opan, “Tradisi Panjang Mulud, Warisan Budaya Kesultanan Banten”, diakses dari https://sites.google.com/site/nimusinstitut/panjang-mulud. 
di masyarakat. Debus dan dzikir mulud termasuk di dalamnya. Debus misalnya seolah mengintegrasikan sekaligus mengatraksikan budaya, magic, kanuragan yang dibungkus dengan bacaan (mantra-mantra) yang meneguhkan wujud keagamaan. Begitupula dengan dzikir mulud, lantunan shalawat dibalut dengan budaya masyarakat yang masih terkesan unsur budaya lebih mendominasi dibanding dengan sakralitas nilai-nilai agama. Hal ini dikarenakan ulama pembawa risalah agama berupaya memadu-madankan budaya sambil memasukkan nilai-nilai religiusitas tanpa mengorbankan budaya yang telah menjadi tradisi turuntemurun. Hal inilah yang menjadi keberhasilan dakwah para pengemban agama, dalam hal ini adalah Islam. [] 


\section{DAFTAR PUSTAKA}

Abdullah, M. Amin, Studi Agama, Normativitas atau Historisitas, Yogyakarta: Pustaka Pelajar, 1996

AG, Muhaimin, Islam Dalam Bingkai Budaya Lokal Potret dari Cirebon, Jakarta: P.T. Logos Wacana Ilmu, 2002

Ambary, Hasan Muarif, Halwany Michrob, John N. Miksic, Katalogus Koleksi Data Arkeologi Banten, (Jakarta: Adrianto, Tashrief, "Ikhtisar Seni Budaya Banten", diakses dari http://tasrief.blogspot.com/2009/05/ikhtisar-seni-budayaBanten.html.

Anggaz, "Ilmu Debus" diakses dari http://anggaz.wordpress. com/2011/05/07/ilmu-debus-2/

Al-Ayubi, Uib Sholahuddin, "Panjang Mulud", ringkasan penelitian Islam Dan Tradisi Lokal Banten (Studi Ritulitas Panjang Mulud di Serang Banten), Lembaga Penelitian IAIN SMH Banten, 2006.

Astri, Ririn, "Tradisi Maulid Nabi di berbagai daerah di Indonesia" diakses dari http://ririnastri.blogspot. com/2011/02/tradisi-maulid-nabi-di-berbagai-daerah. html.

Bruinessen, Martin Van, Kitab Kuning, Pesantren dan Tarekat: Tradisi-Tradisi Islam di Indonesia, Bandung: Mizan, 1999

Dhofier, Zamakhsyari, Tradisi Pesantren: Studi tentang Pandangan Hidup Kyai, Jakarta: LP3ES, 1985

Djajadiningrat, P.A. Hoesein, Tinjauan Kritis tentang Sedjarah Banten, Jakarta: Djambatan, 1983

Depdikbud, 1988); Hamka, Sejarah Ummat Islam, Jakarta: Bulan Bintang, 1976

Disbudpar, “Dzikir Saman”, diakses dari http://www. disbudpar. Bantenprov.go.id/place/dzikir-saman. 
Esposito, John L, Ensiklopedi Oxford: Dunia Islam Modern, Jakarta: Djambatan, 2002

Elfatah, Ahmad, "Hubungan Agama dan Budaya dalam Islam", diakses dari http://www.dakwatuna.com /2012/12/25136/hubungan-budaya-dan-agama-dalamislam/\#ixzz2OckVdWFU

Geertz, Clifford, Agama di Jawa: Konflik dan Interaksi, dalam: Roland Robertson (ed), Agama dalam Analisis dan Interpretasi Sosiologi, Jakarta: Rajawali, 1992

Halwany Michrob, Pemugaran dan Penelitian Arkeologi sebagai Sumbangan Data bagi Perkembangan Sejarah Kerajaan Islam Banten, Skripsi, Jakarta: IPPM, 1981

Hudaeri, Mohammad dkk., "Tasbih dan Golok: Studi tentang Kharisma Kiai dan Jawara di Banten”, ISTIQRA, Jurnal Penelitian Dipertais, Kemenag RI, Ringkasan Laporan Hasil Penelitian Kompetitif Tahun 2002.

Humay MD, "10 Jenis Tarian Daerah Banten", diakses dari http://humaysmash.blogspot.com/2012/12/10-jenistarian-daerah-Banten.html.

Hakim, Lukman, Banten dalam Perjalanan Jurnalistik, (Pandeglang : Banten Heritage, 2006), h. 188=200.

Humay MD, "10 Jenis Tarian Daerah Banten, "diakses dari http://humaysmash.blogspot.com/2012/12/10-jenistarian-daerah -Banten.html.

Hakim, Lukman, Banten dalam Perjalanan Jurnalistik, Pandeglang : Banten Heritage, 2006

http://irfananshory.blogspot.com/2007/04/resensi-buku-dimajalah-tempo.html

http://info-info-umum.blogspot.com/2012/03/mengenalkesenian-debus-dari.html

http://Bantenpos-online.com/2012/02/08/jombang-juara-dzikirmulud 
Irfan, Nia Kurnia Solihat, "Tinjauan Kritis Tentang Sejarah Banten”, Resensi Buku, Majalah Tempo, 1 Oktober 1983

Ismail, Muhammad, Petunjuk Jalan dan Keterangan Bekas Kerajaan Kesultanan Banten, Serang: Saudara, 1983)

Kartodirdjo, Sartono, Pemberontakan Petani Banten 1888, Jakarta: Pustaka Jaya, 1984

Ki Bayu, "Ilmu Ajaib Debus Banten”, diakses dari http://kibayu. wordpress.com/2009/07/01/ilmu-ajaib-debus-ti-leluhur/

Kahin, Pergolakan pada Daerah Awal Kemerdekaan, Jakarta: Graffiti Pers, 1990.

MA. Tihami, Kepimpinan Kiyai di Banten Studi Tentang Agama dan Magic di Desa Pesanggrahan Serang Banten, Serang : P3M STAIN Serang, 1999

, “Kepemimpinan Kyai dan Jawara di Banten,” Tesis S2 Universitas Indonesia, 1992

, "Potret Budaya Dulu, Kini dan Nanti", diakses dari http://Bantenologi.org/index.php?option=com_content\& view=article\&id=83:potret-budaya-Banten-dulu-kini-dannanti\&catid=1:latest-news\&Itemid=50

Maarif, Ahmad Syafi`i, Membumikan Islam, Yogyakarta: Pustaka Pelajar, 1995

Muzakki, Makmun, “Tarekat dan Debus Rifaiyyah di Banten”, Skripsi Fakultas Sastra Universitas Indonesia, 1990

Noorikhsan, Faisal Fadilla, "Menapaki Jejak Jawara Banten", diakses dari http://salmanitb.com/2012/05/menapakijejak-jawara-Banten.

Opan, "Tradisi Panjang Mulud, Warisan Budaya Kesultanan Banten", diakses dari https://sites.google.com/site/ nimusinstitut/panjang-mulud

Poesponegoro, Marwati Djoened dan Nugroho Notosusanto, Sejarah Nasional Indonesia III: Jaman Pertumbuhan 
dan Perkembangan Kerajaan Islam di Indonesia, Edisi Pemutakhiran, Jakarta: Balai Pustaka, 2008

Penyusun Kamus Pusat Pembinaan dan Pengembangan Bahasa DEPDIKBUD, Kamus Besar Bahasa Indonesia, Jakarta: balai Pustaka, 1996

Roesjan, Tb.G., Sejarah Banten, Jakarta: Arief, 1954

Al-Syaqiriy, Muhammad bin 'Abdus Salam Khodr, Al-Sunan wal Mubtada'at Al-Muta'alliqoh Bil Adzkari wa al-Sholawat, Bairut: Darul Fikr, ttp.

Tjandrasasmita, Uka, (Ed.), Sejarah Nasional Indonesia, Jakarta: Depdikbud, 1975

Uka Tjandrasasmita, Sultan Ageng Tirtayasa Musuh Besar Kompeni Belanda, Jakarta: Yayasan Nusalarang, 1967

Widyosiswoyo, Supartono, Sejarah Kebudayaan Indonesia, Jakarta: Universitas Trisakti, 2006 